\title{
Rice Blast Disease in Climate Change Times
}

\author{
Rosangela Bevitori ${ }^{1 *}$ and Raquel Ghini ${ }^{2}$ \\ ${ }^{1}$ Embrapa Rice and Beans, CP 179, ZC 75375-000, Santo Antônio de Goiás, GO, Brazil \\ ${ }^{2}$ Embrapa Environment, CP69, ZC 13820-000 Jaguariúna, SP, Brazil
}

*Corresponding author: Rosangela Bevitori, Embrapa Rice and Beans, CP 179, ZC 75375-000, Santo Antônio de Goiás, GO, Brazil, Tel: (51) 91995512; E-mail: rosangela.bevitori@embrapa.br

Rec date: Oct 28, 2014; Acc date: Oct 30, 2014; Pub date: Nov 4, 2014

Copyright: ( 2014 Bevitori R, et al. This is an open-access article distributed under the terms of the Creative Commons Attribution License, which permits unrestricted use, distribution, and reproduction in any medium, provided the original author and source are credited.

\section{Editorial}

Rice production currently plays an essential role in feeding the world's population and will continue to be in the future, because rice is the most important global staple food in many countries. The production of rice, along with other agricultural crops, will be impacted by climate change. There is still great uncertainty about how climatic and atmospheric changes will affect the future productivity of food crops [1]. Major future impacts of climate change are expected on food security and agricultural incomes, including shifts in production areas across the world [2].

In addition to affecting rice production, climate change may alter pathogen dissemination and development rates, and modify the resistance, growth and metabolism of host plants. The geographical distributions of pathogens are very likely to change, and losses can be expected, in part due to altered effectiveness of control strategies [3]. Thus climate change is a serious threat to agriculture because it can lead to significant changes in the occurrence and severity of plant diseases [4].

Agricultural zones and the geographical distribution of diseases, pests and weeds are projected to change in future climate scenarios, and as a consequence, crop growing areas and seasons are expected to change. Consequently, plant health problems are anticipated to take on greater importance.

Due to their large populations, the ease with which they multiply and become disseminated, and their short generation times, pathogens will likely be among the first organisms to exhibit the effects of climate change [5]. However, the effects of plant diseases differ depending on the pathogen, the host, and environmental conditions and the results of studies of the effects of plant disease have often varied due to the different methodologies used, as well.

Rice is the host of Magnaporthe oryzae (Barr) [anamorph Pyricularia oryzae (Cav.)], which is one of the most destructive and widespread pathogens in all regions of the world where rice is grown, including Brazil. Rice blast disease results from the interaction between a virulent isolate of this pathogen, and a susceptible genotype in the presence of favorable ambient conditions. Predictions on how changes in climate will affect plant health at various spatio-temporal scales are based on extrapolation from expert knowledge, experimental studies, and computer models [6]. However, quantitative analysis of effects of climate change on pathogens is lacking in both field and laboratory studies, or as well as in modeling-based assessments [7].

Luo et al. [8] used models to study the effects of temperature and $\mathrm{UV}-\mathrm{B}$ on rice blast disease and predicted an increase in rice blast severity in several zones of Asia. These investigators showed that changes in precipitation did not affect epidemics and had little effect on the leaf wetness period in their model. In cold subtropical areas, an increase in temperature was found to cause an increase in the severity of disease and in the area under the disease progress curve. These results may be attributable to an increased risk of infection at elevated temperatures. In contrast, in the humid tropics and in warm, humid subtropical regions, such as southern China, the Philippines and Thailand, low temperatures increased the risk of blast epidemics because current temperatures in these regions are higher than temperatures that are favorable for the occurrence of the disease. In another analysis of the same field project, Luo et al. (1998) reported that an increase in UV-B radiation significantly enhanced the occurrence of the disease. In contrast, Finckh et al. [9] found no change in the incidence of rice blast with increased UV-B exposure.

Over 30 years, maximum and minimum temperatures were recorded in three upland rice producing of Brazil, that have negligible (Cuiabá), moderate (Goiânia), and high (Brasília) levels of blast [10]. The measurements were made when the plants were in the stages of panicle emission and maturation and were therefore susceptible to infection. At all locations, there was no major differences in precipitation, but the maximum and minimum temperatures increased each month, and this increase favored higher levels of blast disease. In Brasilia, lower maximum $\left(26.6^{\circ} \mathrm{C}\right.$ to $\left.27.1^{\circ} \mathrm{C}\right)$ and minimum $\left(16.8^{\circ} \mathrm{C}\right.$ to $17.5^{\circ} \mathrm{C}$ ) temperatures were observed as compared with Cuiabá, as well as higher levels of disease incidence. In Cuiabá, the maximum $\left(32.6^{\circ} \mathrm{C}\right.$ to $\left.32.9^{\circ} \mathrm{C}\right)$ and minimum $\left(22.0^{\circ} \mathrm{C}\right.$ to $\left.23.2^{\circ} \mathrm{C}\right)$ temperatures were unfavorable to the disease. This study thus projects that by 2080 the incidence of blast disease will be lower due to the predicted increase in minimum temperatures, which will present values between $22^{\circ} \mathrm{C}$ and $24^{\circ} \mathrm{C}$. Moreover, because the maximum and minimum temperatures will both increase, the severity and incidence of rice blast are expected to fall in these regions in Brazil. However, in contrast, if the temperature increases in cool, temperate climates, those regions may become more susceptible to rice disease. More detailed modeling studies and climate monitoring that take into consideration other factors that affect the disease, would be beneficial.

The impacts of elevated atmospheric $\mathrm{CO}_{2}$ concentrations on the development of rice diseases are not well understood. Ainsworth [11] conducted a meta-analysis to synthesize rice responses to rising atmospheric $\mathrm{CO}_{2}$ and $\mathrm{O}_{3}$ concentrations. On average, high $\mathrm{CO}_{2}$ concentrations will increase rice yields, but elevated temperatures and increased $\mathrm{O}_{3}$ concentrations will dampen these effects. High concentrations of $\mathrm{CO}_{2}$ are expected to increase blast spread [12-14].

Simulation or modeling studies that attempt to predict the impact of climate change on rice blast disease are scarce. For this reason, assumptions are made based on the epidemiology of the disease at specific temperature, humidity and $\mathrm{CO}_{2}$ values. The advantage of this 
Page 2 of 2

method is that the complete cycle of a disease can be considered However, this method is also regarded as somewhat subjective [15].

All phases of the disease cycle, from the germination of spores to the development of lesions, are considerably influenced by climatic factors. The most important climatic factors are temperature and precipitation or the deposition of dew. These factors may be modified by the coming climate changes.

The life-cycle of the rice blast fungus begins when conidia produced on lesions are disseminated and come in contact with rice leaf surfaces. The production phase, release and dissemination phase both occurs under highly humid conditions, $93 \%$ and $92-96 \%$ relative humidity, respectively. Peak spore production occurs during the night when the relative humidity is high $(100 \%)$ and the temperature is approximately $22^{\circ} \mathrm{C}$. Night temperatures over $30^{\circ} \mathrm{C}$ have been shown to coincide with less spore liberation [16]. Consequently, climate change may reduce disease severity in this regard.

To penetrate a leaf to initiate infection, the fungus must overcomes the cuticle barrier, which is a hydrophobic layer covering the epidermis. Soon after the attachment of a spore to the leaf surface, mucilage stored in the spore is liberated. This occurs in wet environmental conditions. This helps the fungus to adhere to the leaf, and this adherence permits conidial germination. A lack of humidity in the form of rain drops can also reduce disease severity. Under these conditions, conidial adherence and penetration are restricted.

The germination of conidia and the onset of infection are highly dependent on water, and starts with the small tube germination after 30 to 90 minutes of contact with water. Appressorium formation occurs on average at $24^{\circ} \mathrm{C}$, but it is uncommon for the appressorium to form at temperatures higher than $28^{\circ} \mathrm{C}$. Fungal penetration requires a minimum of 6-8 hours of wetness and occurs at an optimal temperature of $25^{\circ} \mathrm{C}$. Sporulation then begins on wounds when the relative humidity is at least $93 \%$. However, when the night temperature exceeds $20^{\circ} \mathrm{C}$, infection is absent. Higher temperatures that are predicted to occur with climate change may thus reduce disease incidence.

Rapid growth of lesions is favored by alternating temperatures of $25 / 32^{\circ} \mathrm{C}$ and $20 / 32^{\circ} \mathrm{C}$. The development of lesions occurs 72 hours after inoculation, and the lesions then grow in size and number. After 144 hours of high humidity, the lesions begin to produce spores in abundance, the spores are released and dispersed by the wind, and provide the inoculum for a new cycle of infection [10]. The ideal temperature for sporulation ranges from $25^{\circ} \mathrm{C}$ to $28^{\circ} \mathrm{C}$, while the optimal relative humidity is between $89 \%$ and $93 \%$. Mild temperatures (16 to $24^{\circ} \mathrm{C}$ ) maintain the sporulation capacity of lesions.

Rainfall washes the newly generated spores from the plant, thereby reducing the available amount of inoculum, and on rainy days, spores spread over smaller area [10]. However, the failure of released spores to act as inoculum in the next cycle does not appear to increase in incidence of disease.

Strategies for adapting to climate change must be developed to limit the development of economic and social problems. Disease-resistant- and stress-tolerant rice varieties, for example, can be grown to prevent reduced crop productivity associated with diseases, and with heat and drought stress. Breeding new rice cultivars adapted to the new climate demands is necessary. Vulnerability mapping, early warning systems and coordination across sectors can prevent losses, and join efforts among investigators from a variety of fields will enable the development of successful and sustainable adaptation strategies.

\section{References}

1. Gornall J, Betts R, Burke E, Clark R, Camp J, et al. (2010) Implications of climate change for agricultural productivity in the early twenty-first century. Philos Trans R Soc Lond B Biol Sci 365:2973-2989.

2. 2-IPCC - Intergovernmental Panel on Climate Change (2014) Climate Change 2014: impacts, adaptation, and vulnerability. Part A: Global and sectoral aspects. Contribution of Working Group II to the Fifth Assessment Report of the IPCC. Cambridge University Press, Cambridge.

3. Coakley SM, Scherm H, Chakraborty S (1999) Climate change and plant disease management. Annu Rev Phytopathol 37: 399-426.

4. Ghini R, Bettiol W, Hamada E (2011) Diseases in tropical and plantation crops as affected by climate changes: current knowledge and perspectives. Plant Pathol 60: 122-132.

5. Scherm H, Sutherst RW, Harrington R, Ingram JSI (2000) Global networking for assessment of impacts of global change on plant pests. Environ Pollut 108: 333-341.

6. Pautasso M, Döring TF, Garbelotto M, Pellis L, Jeger MJ (2012) Impacts of climate change on plant diseases - opinions and trends. Eur J Plant Pathol 133: 295-313.

7. Luck J, Spackman M, Freeman A, Trebicki P, Griffiths F, et al. (2011) Climate change and diseases of food crops. Plant Pathol 60: 113-121.

8. Luo Y, Tebeest DO, Teng PS, Fabellar NG (1995) Simulation studies on risk analysis of rice leaf blast epidemics associated with global climate change in several Asian countries. J Biogeogr 22: 673-678.

9. Finckh MR, Chavez AQ, Dai Q, Teng PS (1995) Effects of enhanced W-B radiation on the growth of rice and its susceptibility to rice blast under greenhouse conditions. Agr Ecosyst Environ 52: 223-233.

10. Prabhu AS, Silva CS, Filippi MC (2008) Impacto potencial das mudanças climáticas sobre as doenças de arroz no Brasil. In Ghini R, Hamada E (eds.). Mudanças Climáticas: impactos sobre doenças de plantas no Brasil. p.140-158.

11. Ainsworth EA (2008) Rice production in a changing climate: a metaanalysis of responses to elevated carbon dioxide and elevated ozone concentration. Glob Change Biol 14: 1642-1650.

12. McElrone AJ, Reid CD, Hoye KA, Hart E, Jackson RB (2005) Elevated CO2 reduces disease incidence and severity of a red maple fungal pathogen via changes in host physiology and leaf chemistry. Glob Change Biol 11: 1828-1836.

13. Kobayashi T, Ishiguro K, Nakajima T, Kim HY, Okada M, et al. (2006) Effects of elevated atmospheric $\mathrm{CO} 2$ concentration on the infection of rice blast and sheath blight. Phytopathology 96: 425-431.

14. Gória MM, Ghini R, Bettiol W (2013) Elevated atmospheric CO2 concentration increases rice blast severity. Trop Plant Pathol 38: 253-257.

15. Juroszek P, Tiedemann A von (2013) Climate change and potential future risks through wheat diseases: a review. Eur J Plant Pathol 136: 21-33.

16. Espinoza IG, Shohara K (2003) Investigación relativa a la ocurrencia de Piricularia en trigo. (v.2), Centro Tecnológico Agropecuário en Bolívia, Santa Cruz. 